\title{
ALGAL FLORA OF NAGDAHA LAKE, LALITPUR, NEPAL
}

\author{
Bishnu Prasad Parajuli \\ Department of Botany, Prithvi Narayan Campus, Tribhuvan University, Pokhara, Nepal
}

\begin{abstract}
This paper is a report of algal flora of Nagdaha Lake, Dhapakhel, Lalitpur. Algal Samples were collected out in the months of May, August and December 1996, from four different sampling sites of the lake. From the investigation, 25 different algal taxa belonging to 16 families were observed. Among them, 17 species were observed in summer and winter season while in rainy season 19 species were observed.
\end{abstract}

Keywords: Algae, families, seasonal variation, species

\section{INTRODUCTION}

The algal flora of Nepal, by taxa, comprises of 687 species belonging to 150 genera and 50 families (Baral 1995). Algal flora are economically important in a number of ways like food value, extraction of minerals, green manure production, nitrogen fixation etc. In Nepal, algae have been recorded from tropical habitats of Terai to arctic habitats in the Himalayas up to $4850 \mathrm{~m}$. The majority of algae are fresh water forms, only a few species are terrestrial and sub-aerial forms. The Terai and Siwalik belt are favorable for the growth of algae as these zones have hot and humid climate. The desmids, diatoms and blue green algae are the most recorded group of algae. Hirono (1995) suggests that higher attitudes will be rich in diatoms flora. The main objectives of the current research are (i) to enumerate the algal taxa of Nagdaha Lake and (ii) to study the seasonal fluctuation of algal taxa within the study site.

\section{MATERIALS AND METHODS}

\section{Study Site}

The study was conducted at Nagdaha Lake, Dhapakhel, Lalitpur. The study site was selected based on catchment area, substrate structure, algal occurrence and human activities.
Nagdaha is a sacred lake. It lies about five km south from Patan city in Dhapakhel village on the way to Godavari. Water is received from annual monsoon rain, ground water seepage and a small stream inlet. The outlet of lake is on the eastern side. The lake is zigzag in shape. It occupies an area of about five hectrares. The lake attains a maximum depth of seven meters. It is surrounded by agricultural land. The bank of the lake is being protected by bamboo mesh net to control soil erosion. Due to death and decay of macrophytes, and the dead macrophytes collected at the bottom of lake and agricultural soil run off during rainy reason, the lake is being shrunken and succession take place. Due to succession, wet land vegetation occurs in one corner of the lake. 


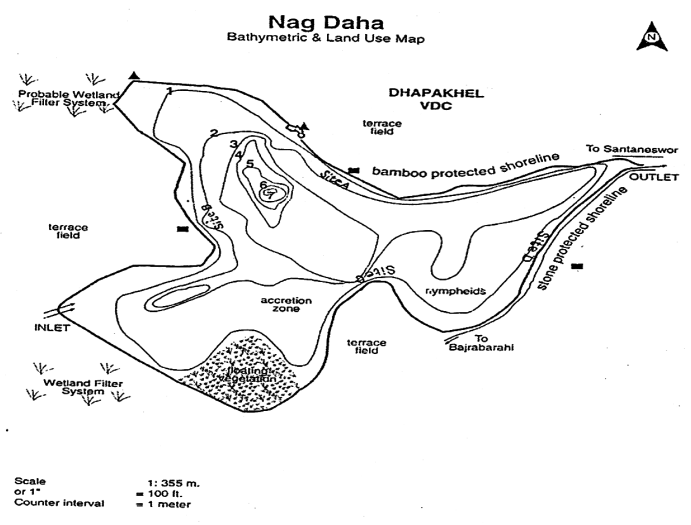

Fig. 1 Nagdaha Lake

Fig. 1 Nagdaha Lake

\section{Data collection}

The data were collected based on visual observations, field works, lab works and information collected from local people as primary source. Samples of algal were collected out in the months of May, August and December 1996. Algal samples were collected from four different sampling sites of the lake in proclaimed plastic bottles with the help of siphon sampler. The samples were collected from surface and up to depth of 3 meters. Two liter of water from each depth was filtered through the plankton net (mesh size 45.1) and it was transferred to plastic bottles. Then, the samples were preserved in the Lysol's solution $(7 \mathrm{~m} \mathrm{1/1)}$ and stored in a cool and dark place. For identification of algal taxa,

Table 1 Algal taxa of Nagdaha Lake (1996)

\begin{tabular}{lllll}
\hline Algal Taxa & Classes & Summer & Rainy & Winter \\
\hline Oscilliatoria species & Cynophyceae & - & + & + \\
Anabaena species & Cynophyceae & - & - & + \\
Lyngbya species & Cynophyceae & - & + & + \\
Spiruliana species & Cynophyceae & + & - & - \\
Nostoc species & Cynophyceae & - & + & + \\
Chara species & Chlorophyceae & + & + & +
\end{tabular}

the standard keys provided by Prescott (1978), West and West (1978), Bishwas (1995) and APHA (1995) were followed.

\section{RESULT AND DISCUSSION}

From the biological point of view, the present investigation revealed that different algae have inhabited Nagdaha Lake. Altogether, 25 algal taxa belonging to 16 different families have been observed. Maximum (76\%) algal taxa were observed during rainy season. While minimum $(60 \%)$ algal taxa were observed during summer and winter reason. The detail picture of data analysis of Nagdaha Lake is presented in fig. 2 and Table 1). Current result suggests the seasonal variation in algal diversity with high abundance in rainy season. This may imply that rainy season is the optimal season for the growth of algae. Consistent to this result, Hickel (1973) found seasonal variation of algal diversity from various lakes of Pokhara such as Phewa, Rupa, Begnas and Khaste and from Taudaha and Nagdaha of Kathmandu valley. Similar to the current result, Pradhan (1995) and Aryal (1995) have also studied the seasonal variation in algal diversity. Following their findings and the current finding, it is suggested that the degree of water pollution is one of the major factors that affect the diversity of algal growth. 
Chlorella species

Oedogonium species

Spirogyra species

Zygnema species

Stigoclonium species

Cladophora species

Cosmarium species

Closteiu species

Pediastrum species

Antinotaneum species

Scenedesmus species

Flagillaria species

Diatoma species

Synedra species

Navicula species

Pinnularia species

Stauroneis species

Gomphonema species

Nitzschia species
Chlorophyceae

Chlorophyceae

Chlorophyceae

Chlorophyceae

Chlorophyceae

Chlorophyceae

Chlorophyceae

Chlorophyceae

Chlorophyceae

Chlorophyceae

Chlorophyceae

Bacillaryophyceae

Bacillaryophyceae

Bacillaryophyceae

Bacillaryophyceae

Bacillaryophyceae

Bacillaryophyceae

Bacillaryophyceae

Bacillaryophyceae
Total No. of species in different season

17

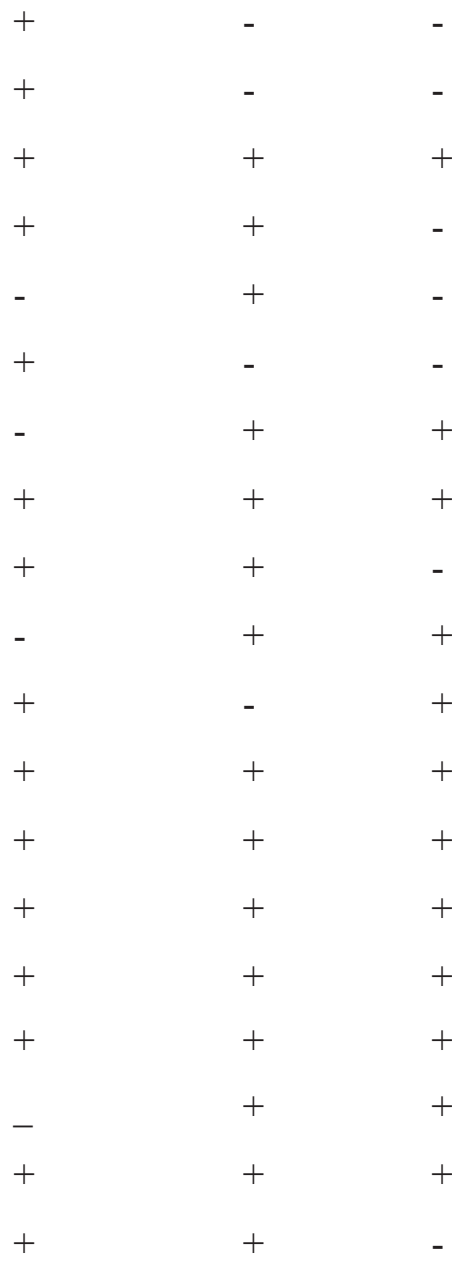

+ Present, - Absent

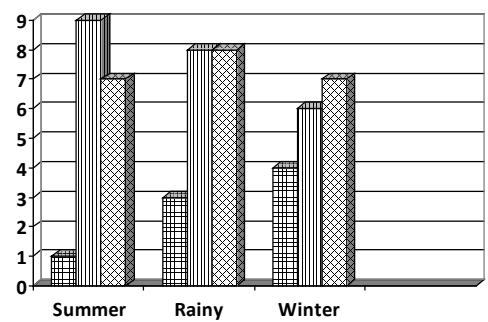

毘 Bacillariophyceae

西 Chlorophyceae

Cyanophyceae

Fig. 2 Seasonal variation of algal taxa in Nagdaha Lake

\section{ACKNOWLEDGEMENTS}

I am extremely grateful to Prof. Dr. P.K. Jha, Central Department of Botany, Tribhuvan University for supervision and constructive suggestion at every step of the work. I extend my gratitude to prof. Dr. C.B. Thapa for constructive suggestions. My special thank goes to all members of fisheries research division and fisheries research centre, NARC Godavari for their help in providing laboratory facilities and valuable suggestions during this work. 


\section{REFERENCES}

APHA, AWWA and WPCF (1995). Standard method for examination of water and wastewater $19^{\text {th }}$ edition. American Public Health Association, American water work and association, Water pollution control Federation, Washington, D.C.

Aryal, S. (1995). Study on factors affecting the distribution and diversity of Diatoms in lotic system. M.Sc. Dissertation, Central Department of Botany, Tribhuvan University, Kirtipur, Nepal.

Baral, S.R. (1995). Enumeration of the algae of Nepal. Biodiversity profiles project, publication No. 11, Nepal.

Biswas, K. (1980). Common and Blackish water algal flora of India and Burma. Botanical survey of India, 15: 105, Periodical Export Book Agency, India.

Hickel, B. (1973). Limnological investigation in lakes of the Pokhara Valley, Nepal. Int. Rev. Ges. Hydrobiol 58(5): 654-672.
Hirono, M (1995). Fresh water Fauna and Flora of Nepal Himalaya, Scientific report of Japanese expedition- Nepal Himalaya, Kyoto, Japan.

Pradhan, P. (1995). Ecological distribution pattern of algal flora. MSc Dissertation, Central Department of Botany, Tribhuvan University, Kirtipur, Nepal.

Prescott, G.W. (1978). How to know fresh water algae? $3^{\text {rd }}$ edition, W.M.C. Brown Company, USA.

West, W. and G.S. West (1978). Fresh water algal from Burma including a few from Bengal and Madras: 260. Periodical Experts Book Agency.

(Received 8 March 2017, revised accepted 13 June 2017) 